EDITORIAL

\title{
Lensa kontak: keamanan dan pencegahan komplikasi
}

\author{
Husnun Amalia \\ Departemen Ilmu Penyakit Mata, Fakultas Kedokteran Universitas Trisakti \\ E-mail: husnun_a@trisakti.ac.id
}

Lensa kontak saat ini dikenal oleh masyarakat secara luas dan sering digunakan dalam kehidupan sehari-hari. ${ }^{(1)}$ Lensa kontak adalah alat bantu yang diletakkan di permukaan kornea, mudah digunakan, nyaman untuk beraktivitas dan berolahraga. Fungsi utamanya adalah untuk mengatasi gangguan refraksi dengan keunggulan memberikan lapang pandang lebih luas dan lebih baik secara estetik. (2) Saat ini penggunaannya telah berkembang menjadi atribut mode dan estetika. ${ }^{(3)}$ Indikasi penggunaan lensa kontak lainnya adalah terapeutik (ulkus kornea, erosi kornea, albino, aniridia, post operasi kornea), preventif simblefaron, diagnostik dan occupational (olahragawam, pilot, aktor). ${ }^{(2)}$ Lensa kontak yang sering digunakan adalah lensa kontak lunak (softlens) yang berbahan hidrogel atau silicon hidrogel. ${ }^{(4)}$

Produk lensa kontak keunggulannya semakin bervariasiuntuk menunjang kebutuhan penggunanya dengan menyesuaikan warna, kandungan air dan ukuran diameter. ${ }^{(5)}$ Industri lensa kontak saat ini terus mengoptimalkan kualitas untuk meningkatkan compatiblity physiological, kenyamanan dan keamanan penggunanya. ${ }^{(4)}$ Terdapat 4 tipe lensa kontak yaitu Rigid gaspermeable (RGP), softlens, Extended-wear(RGP atau softlens)danExtended-wear disposable. Softlens memiliki keuntungan berbahan plastik tipis, fleksibel yang mempermudah masuknya oksigen ke mata, mudah digunakan dan waktu adaptasi pendek. Hal ini meningkatkan kenyamanan penggunanya. ${ }^{(3)}$ Saat ini pengguna lensa kontak di dunia mencapai 140 juta orang. (6) Penggunaannya semakin meningkat karena lensa kontak dapat meningkatkan kualitas hidup penggunanya. ${ }^{(1)}$

Penggunaan lensa kontak sangat aman dan tidak memerlukan keahlian khusus, namun dapat menyebabkan masalah dan komplikasi yang serius bila tidak menggunakan dengan cara yang benar. (3) Komplikasi yang terjadi sangat berhubungan dengan perilaku higiene dalam menggunakan dan merawat lensa kontak. Pengguna lensa kontak yang tidak patuh mencapai $40-91 \%{ }^{(7)}$ Masalah yang terjadi bervariasi mencapai $0,2-94 \%$ dengan keluhan ketidaknyamanan, neovaskularisasi kornea, keratitis, ulkus kornea, dry eye, ptosis, alergi hingga kekeruhan kornea. ${ }^{(1)}$ Penggunaan lensa kontak dikontraindikasikan pada seseorang dengan gangguan mental, blefaritis kronik dan stres rekuren, konjungtivitis kronis, dryeye syndrome, distrofi dan degenarasi kornea, episkleritis, skleritis dan iridocyclitis. ${ }^{(2)}$

Kebersihan jari-jari adalah hal terpenting untuk menghindari timbulnya masalah. Langkah yang harus diperhatikan saat memasang maupun melepaskan lensa kontak adalah; 1) pengguna harus mencuci kedua tangannya dengan sabun antiseptik yang tidak mengandung parfum atau lotion kemudian dikeringkan menggunakan linen bersih sebelum menyentuh lensa kontak; 2) saat akan memasang lensa kontak diambil dan diletakkan di telapak tangan, lalu dibersihkan dengan menggosok dan membilas. Berikan 2-3 tetes cairan kemudian lensa kontak digosok ringan menggunakan jari telunjuk dengan gerakan melingkar dari dalam ke luar selama 15 detik di kedua sisi. Setelah itu, lensa kontak dibilas dengan cairan garam fisiologis steril yang mengalir lalu diletakkan di ujung jari telunjuk tangan dominan pasien. Pastikan permukaan lensa kontak yang akan bersentuhan dengan bola mata telah benar; 3) jari tengah di tangan yang sama digunakan untuk menarik dan menahan kelopak mata bawah; 4) untuk menarik dan menahan kelopak mata atas, dapat digunakan jari telunjuk tangan lainnya; 5) selanjutnya pandangan mata diarahkan ke atas dan lensa kontak dipasang di bagian bawah bola mata yang berwarna putih lalu kelopak mata atas 
dan bawah dilepaskan; 6) pandangan diarahkan ke bawah dalam keadaan mata tertutup dan mata dipejamkan beberapa saat, maka posisi lensa kontak akan berada di tengah bola mata. ${ }^{(8)}$

Tindakan yang dapat dilakukan untuk mencegah timbulnya masalah pada pengguna lensa kontak adalah; (1) selalu mencuci tangan sebelum menggunakan lensa kontak; (2) bersihkan lensa kontak dengan hati-hati secara rutin, gosok lensa kontak dengan menggunakan jari-jari tangan dan bilas dengan air bersih sebelum merendam lensa kontak dalam larutan multi-fungsi pada malam hari; (3) simpan lensa yang digunakan dalam kotak penyimpanan dan ganti kotak tersebut setiap 3 bulan. Selain itu, bersihkan kotak setelah menggunakannya; (4) gunakan produkproduk yang telah disarankan oleh dokter mata anda untuk membersihkan dan mendesinfeksi lensa kontak anda; (5) selalu ikuti rekomendasi lensa kontak yang telah direncanakan oleh dokter mata anda (6) lepaskan lensa kontak anda sebelum berenang atau mandi; (7) lakukan pemeriksaan mata dan lensa kontak anda secara rutin kepada dokter mata. ${ }^{(9)}$

\section{DAFTAR REFERENSI}

1. Alipour F,Khaheshi S, Soleimanzadeh $\mathrm{M}, \quad$ HeidarzadehS.Contact Lens-related Complications: A Review. J Ophthalmic Vis Res 2017; 12(2): 193-204. DOI: 10.4103/jovr. jovr_159_16

2. Sitompul R. Perawatan Lensa Kontak untuk Mencegah Komplikasi. eJKI 2015; 3(1):77-85. DOI: https://doi/org/10.23886/ejki.3.4811.

3. Nisar S, Alqahtani SS, Fayez F, Alqhtani H, Alrowibah H, Aldulhum A. Comparison of Contact Lens Hygiene Compliance and Self-Management Behaviors between Medical and Non-Medical Students in Saudi Arabia. J Ophthalmol Clin Res2018; 2(2): 1-3

4. Kim E, Saha M, Erhmann K. Mechanical Properties of Contact Lens Materials. Eye \& Contact Lens Science \& Clinical Practice. 2017; 0(0):1-9.DOI: 10.1097/ICL.0000000000000442.

5. Adlhiyah L, hmustafidah H. Sistem Pendukung Keputusan Pemilihan Lensa Kontak (softlens) Menggunakan Metode Simple Additive Weighting (SAW). Juita 2016; 4(2):105-15. DOI: 10.30595/ juita.v0i0.1355

6. Efron N, Morgan PB, Woods CA: International Contact Lens Precribing Survey Consortium : International survey of contact lens prescribing for extended wear. Optom Vis Sci 2012;89:122. DOI:10.1097/OPX.0b013e31823ee077

7. Bui TH, Cavanagh HD, Robertson AD. Patient Compliance During Contact Lens Wear: Perceptions,Awareness, and Behavior. Eye Contact Lens 2010; 36(6): 334-9. doi:10.1097/
ICL.0b013e3181f579f7.

8. Vaughan. Oftalmologi Umum. 17th ed. Jakarta: EGC; 2009.

9. Dartt AD. Neutral regulation of lacrimal gland secretory processe relevance in dry eye disease. Prog Retin Eye Res. 2009;28:155-177. DOI: 10.1016/j.preteyeres.2009.04.003 